九州大学学術情報リポジトリ

Kyushu University Institutional Repository

\title{
An Investigation of the Transformed Forestry Sector in Japan and Taiwan
}

Weng, Pei-Yi WENG

Department of Horticulture and Landscape Architecture, National Taiwan University

Chaing, Yen-Cheng

Department of Landscape Architecture, National Chiayi University

Sato, Noriko

Laboratory of Forest Policy, Faculty of Agriculture, Kyushu University

Chang, Chun-Yen

Department of Horticulture and Landscape Architecture, National Taiwan University

https://doi.org/10.5109/27381

出版情報: 九州大学大学院農学研究院紀要. 58 (2)，pp.475-483，2013-09. Faculty of Agriculture， Kyushu University

バージョン :

権利関係 : 


\title{
An Investigation of the Transformed Forestry Sector in Japan and Taiwan
}

\author{
Pei-Yi WENG ${ }^{1}$, Yen-Cheng CHIANG ${ }^{2}$, Noriko SATO ${ }^{3}$ \\ and Chun-Yen CHANG ${ }^{1 *}$
}

\author{
Laboratory of Forest Policy, Division of Forest Environmental Sciences, \\ Department of Agro-environmental Sciences, Faculty of Agriculture \\ Kyushu University, Fukuoka 812-8581, Japan \\ (Received April 26, 2013 and accepted May 9, 2013)
}

\begin{abstract}
Forests provide various services and benefits, including national land conservation, water preservation, ecological conservation, forest recreation, and timber production. Although Japan established the first Forest Act as early as 1897, this article focuses on the period after World War II until now. Both Japan and Taiwan have established laws and regulations concerning forests. Various laws and regulations have resulted in different forest and forestry policies, the implementation of which can be divided into several periods. The purpose of this study was to conduct a policy comparison of Japan and Taiwan to understand the history of related regulatory amendments, thereby providing a reference basis for the sustainable development of the forest industry. The research results showed that in addition to an increased emphasis on sustainable forest management following international trends, the focus of postwar forestry developments of the two countries transformed from economic benefits based on timber production to multifunctional benefits including forest recreation. In the future, the governments of both countries must focus on hillside hazards and the low domestic timber self-sufficiency rate. Citizens of both countries value national land conservation as well as recreation and enjoyment; therefore, future forestry policies of Japan and Taiwan should strive for the balance between the ecological and economic functions of forests through adjustments to achieve sustainable forest management.
\end{abstract}

Key words: forest and forestry, policy, ecological function, economic function, sustainable management

\section{INTRODUCTION}

In addition to generating primary and secondary products, forests provide various functions and benefits, including forest recreation, soil and water conservation, air regulation, drought prevention, buffer zone effects, biodiversity, and carbon storage. Wang (2005) identified the following five major functions of forests in Taiwan: soil conservation, water conservation, environmental protection, forest recreation, and lumber manufacturing. Nagasakiya (2005) indicated that the central forest functions of Japan have shifted from timber production and water preservation to the current equal emphases on timber production, water preservation, hillside disaster prevention, living environmental conservation, and health care culture. According to public surveys conducted in Japan in 2007 and 2011, Japanese people perceived that the following forest-based benefits were of primary importance: soil conservation, prevention of global warming, health care and recreation, wildlife, and outdoor education. This ranking shows that the benefits of forest recreation have attracted increasing attention. Furthermore, in 2007 Japanese survey, the benefits of manufacturing lumber and the production of wood products was ranked last, which suggests

\footnotetext{
1 Department of Horticulture and Landscape Architecture, National Taiwan University, Taipei 10673, Taiwan

2 Department of Landscape Architecture, National Chiayi University, Chiayi 60004, Taiwan

3 Professor, Laboratory of Forest Policy, Faculty of Agriculture, Kyushu University, Fukuoka 812-8581, Japan

* Corresponding author (E-mail: cycmail@ntu.edu.tw)
}

that forest benefits based on wood materials and products are no longer a trend in Japan (Cabinet Office, 2007, 2011). Liu (2004) categorized the benefits of Taiwan's forests into ecological, public welfare, recreational, health, and economic benefits. In addition, Liu indicated that forests in Taiwan previously functioned as lumber sources, producing economic benefits. However, in recent years, the importance of the lumber industry has gradually decreased, and the importance of recreational benefits has gradually increased. In summary, the development of the forest sector both in Japan and Taiwan has transformed from the economic benefits of lumber manufacturing to the benefits of recreational uses for forestland.

Although forest use in Taiwan began during the Qing Dynasty, people of this period possessed limited knowledge of Taiwanese forests; thus, only camphor woods were utilized (Huang, 2005). Taiwan did not systematically utilize forest resources, such as the delineation of forest areas and establishment of relevant forest management systems, until the Japanese colonial period. Although certain literature indicated that the forest use in Taiwan during the Japanese colonial period was focused more on logging than on afforestation (Lee and Hsu, 2010), other related studies have contended that the Nationalist government performed more forest logging than the Japanese colonial administration did (Yao, 2004). Significant differences exist in the implementation of forest and forestry policies under the management of different governments. This research examined the similarities and differences between the transformations in Taiwan and Japan forestry since WWII. 


\section{Study purpose}

Taiwan is a densely populated island with many mountains and few plains. Taiwan's natural resources are similar to those of Japan. Furthermore, the primary purpose of forestry in both countries has changed from timber production to other uses, which are forest recreation in Taiwan and multiple uses in Japan. Because of transitions in society, Japan spent years transforming the Forestry Basic Act, which supported the manufacturing of domestic lumber, into the Forest and Forestry Basic Act, which develops the diverse functions of forests (Sakai, 2004). In addition, Japan has developed several laws and regulations related to forest recreation, including the Act on Special Measures concerning Reform of National Forest Business Management and the Act on Special Measures concerning Forest Health Function Enhancement. Relevant laws and regulations that facilitate the development of forest recreation are also followed in Taiwan, such as the Managerial Principle and Policy for the Forest Industry in Taiwan, the Reformation Plan for Forest Management in Taiwan, the Forest Act, and the Guidelines for Government or Privately-Owned Forest Recreation Areas in Taiwan (Forestry Bureau, 2012). The purpose of this research was to conduct a policy comparison between Japan and Taiwan to understand the history of related regulatory amendments, thereby providing a reference basis for the sustainable development of the forest industry.

\section{OVERVIEW OF FORESTS AND FORESTRY}

\section{Japan}

According to the Forestry Agency (2011) of Japan, forests in Japan comprise 25.1 million hectares, which account for $67.3 \%$ of the total national land. Among these, six types of recreational forests, which are natural recreation forest, nature education forest, forest landscape (scenery forest), sport forest, field sports area, and scenic forest, account for 388,000 hectares, or 1.6\% of the total forest area. The number of recreational forest users has decreased yearly from 2002 to 2010 (Table 1). In Japan, forests can be delineated into natural forests and plantations, which respectively account for 53.3\% and $41.2 \%$, and the remaining $5.5 \%$ consist of clearfell areas and bamboo groves. By ownership delineation, $30.6 \%$ of the forest land is state forests and $69.4 \%$ are non-state forests (local governmental and private forests) (Table 2).

Forestry productions of Japan have declined. The timber production yield in 1960 was 63.8 million cubic meters, which decreased to 16.9 million cubic meters in 2002 because of an increase in timber imports; it has since risen to 20.1 million cubic meters in 2011 (Table 3). The timber self-sufficiency rate of Japan was greatly reduced during the period from 1955 to 2000 (94.5\% to $18.2 \%$, respectively), and has since slightly increased to $27.0 \%$ in 2011 . The number of forest workers decreased from 220,000 in 1975 to 50,000 in 2007, slightly increasing to 80,000 in 2010 (Forestry Agency, 2011). The declines of Japanese forestry and the number of forest workers have shown negative effects on forest management. Many forests lack adequate protection and management because an insufficient amount of workforce is available to perform thinning or piling, resulting in forest degradation, poorly conserved soil and water, and reduced water conservation function of forests.

Table 1. Number of users of recreational forests in Japan from 2002 to 2010 (in millions)

\begin{tabular}{ccccccccccc}
\hline Year & 2002 & 2003 & 2004 & 2005 & 2006 & 2007 & 2008 & 2009 & 2010 \\
\hline Visitors & 156 & 152 & 147 & 143 & 139 & 131 & 123 & 110 & 116 \\
\hline
\end{tabular}

Source: Forestry Agency (2011)

Table 2. Current percentage of forests in Japan and Taiwan

\begin{tabular}{rcccc}
\hline & $\begin{array}{c}\text { Forests/National } \\
\text { land }\end{array}$ & $\begin{array}{c}\text { Recreational forests/ } \\
\text { Total forests }\end{array}$ & $\begin{array}{c}\text { State forests/Total } \\
\text { forests }\end{array}$ & $\begin{array}{c}\text { Natural forests/Total } \\
\text { forests }\end{array}$ \\
\hline Japan & $67.3 \%$ & $1.6 \%$ & $30.6 \%$ & $53.3 \%$ \\
Taiwan & $58.5 \%$ & $1.9 \%$ & $78.0 \%$ & $73.0 \%$ \\
\hline
\end{tabular}

Source: Forestry Agency (2011); Forestry Bureau (2013a)

Table 3. Domestic timber yield and quantity of timber exports and imports (in million cubic meters)

\begin{tabular}{|c|c|c|c|c|c|c|c|c|c|c|}
\hline Year & 2002 & 2003 & 2004 & 2005 & 2006 & 2007 & 2008 & 2009 & 2010 & 2011 \\
\hline Domestic timber yield & 16.9 & 17.0 & 17.3 & 17.9 & 18.3 & 19.3 & 19.4 & 18.3 & 18.9 & 20.1 \\
\hline Imports quantity & 72.8 & 71.9 & 74.1 & 69.5 & 70.0 & 64.6 & 60.1 & 46.5 & 53.0 & 54.3 \\
\hline Exports quantity & 0.6 & 0.8 & 0.8 & 0.8 & 0.9 & 0.9 & 0.8 & 0.7 & 1.6 & 1.5 \\
\hline
\end{tabular}

Source: Forestry Agency (2011) 
Improving this situation has become a major policy concern for forest management in Japan.

\section{Taiwan}

According to the Forestry Bureau (2013a), the current total forest area of Taiwan is approximately $2,102,400$ hectares, accounting for $58.5 \%$ of the total national land. The forests of Taiwan consist of 73.0\% natural forest, $20.0 \%$ plantation, and $7.0 \%$ bamboo groves. Of the total forests, $78.0 \%$ is state forest, $2.7 \%$ is experimental forest area, and $19.3 \%$ is local government and privately owned forest (Table 2) (Forestry Bureau, 2013b). The volume of timber exports in 2011 was 0.5 million cubic meters, which was far less than that of timber imports (Table 4). Currently, 21 government-owned forest recreation areas exist in Taiwan, which account for 41,000 hectares or $1.9 \%$ of the total forest area (Lee and Hsu, 2010). In Taiwan, the revenues and users of forest recreation increased annually from 2002 to 2011 (Table 5).

Since 1895, Taiwan has established three official forest regions: Alishan, Basianshan, and Taipingshan. The forestry policy during the 1960s encouraged timber imports and the enhancement of wood-processing techniques with the objective of developing the export industry of wood products. The plywood industry originated in the 1950s, and industries of paper pulp, wood products, and furniture flourished in the late 1970s. However, these industries suffered a decline during the 1980s (Lee and Hsu, 2010). After decades of deforestation during the Japanese colonial period and the Nationalist government administration, the water conservation function of many forests was damaged, resulting in several major floods in the plain areas. Consequently, Taiwan was prompted to establish forest laws and regulations such as the Taiwan Forestry Management Reform Plan and the Forest Act. In 1991, a nationwide logging ban was enforced on natural forests, water conservation forests, and forests in ecological protection areas, nature reserves, and national parks, ending 46 years of postwar deforestation.

\section{AMENDMENT HISTORY OF RELATED LAWS AND REGULATIONS}

\section{Japan}

Totman (1989) indicated that Japan has consistently devoted considerable effort to conserving and using forest resources; forests are closely connected to life, culture, industry, and the economy. In Japan, the ratio of planted forests to natural forests is 1:1.4, highlighting the importance of the forestry sector in the historically agricultural society. Japan established the first Forest Act as early as 1897 (Forestry Agency, 2013b), and since then, many laws and regulations related to forests and forestry management have been passed. Chronologically, these include the National Forestry Act in 1899, Regulations on Official Afforestation of Public Forests in 1920, Act on National Insurance for Forest Fires in 1937, Act on Temporary Measures concerning Afforestation and Forest Pests and Disease Control Act in 1950, Act on Temporary Measures concerning Conservation Forest Maintenance in 1954, Act on Public Forest Development Corporations in 1956, Forestry Basic Act in 1964, Act on Forestry Improvement Funds in 1976, Act on Temporary Measures concerning Forestry Revitalization Financing in 1979, Act on Advancement of Forest Maintenance Backed by Green Fund in 1995, Act concerning the Security of Forestry Work Force and Act on Special Measures concerning Assurance of Stable Supply of Timber in 1996, Act on Special Measures concerning Reform of National Forest Business Management in 1998, the Act on Special Measures concerning Advancement of Implementation of Forest Thinning in 2008, and Forest and Forestry Regeneration Plan in 2009 (Forestry Agency, 2013b).

Among these, the Forestry Basic Act was renamed the Forest and Forestry Basic Act in the July 2001 amendment, and has become central in the legal system of forest and forestry. From 1960 to 1970, a rapid

Table 4. Timber imports and exports of Taiwan region (in million cubic meters)

\begin{tabular}{|c|c|c|c|c|c|c|c|c|c|c|}
\hline Year & 2002 & 2003 & 2004 & 2005 & 2006 & 2007 & 2008 & 2009 & 2010 & 2011 \\
\hline Imports quantity & 6.7 & 7.3 & 7.7 & 7.5 & 6.4 & 6.8 & 6.7 & 3.9 & 6.6 & 6.4 \\
\hline Exports quantity & 1.3 & 1.2 & 1.2 & 1.1 & 1.1 & 1.0 & 0.8 & 0.4 & 0.5 & 0.5 \\
\hline
\end{tabular}

Source: Forestry Bureau (2013a)

Table 5. Revenues of forest recreation area of Forestry Bureau

\begin{tabular}{|c|c|c|c|c|c|c|c|c|c|c|}
\hline Year & 2002 & 2003 & 2004 & 2005 & 2006 & 2007 & 2008 & 2009 & 2010 & 2011 \\
\hline Grand total (million NT \$) & 52 & 58 & 56 & 64 & 75 & 82 & 82 & 89 & 89 & 106 \\
\hline Admission ticket (thousand) & 2,819 & 3,025 & 2,601 & 2,666 & 3,149 & 3,273 & 3,121 & 3,687 & 2,856 & 3,701 \\
\hline Parking vehicle (thousand vehicles) & 364 & 401 & 340 & 319 & 393 & 418 & 365 & 397 & 332 & 348 \\
\hline Accommodation (thousand) & 349 & 354 & 296 & 286 & 330 & 368 & 381 & 399 & 399 & 412 \\
\hline
\end{tabular}

Source: Forestry Bureau (2013a) 
increase in imported round log forced Japan to pass the Forestry Basic Act in 1964 to establish a forestry policy that supported domestically manufactured lumber. However, beginning in 1990, the global environment became an issue gaining increased international attention, and international environmental agreements such as the Forest Principles, the United Nations Framework Convention on Climate Change, and the Convention on Biological Diversity were signed. Subsequently, Japan actively participated in global environmental protection activities, devoting considerable effort to establishing the Kyoto Protocol. In addition, Japan's forestry policy was transformed from the Forestry Basic Act, which advocated government assistance to enable forestry and lumber manufacturers to achieve their production goals, into the Forest and Forestry Basic Act, which primarily aims to develop the diverse functions of forests (Sakai, 2004).

The postwar forest and forestry policy of Japan can be classified into three stages and five policy periods after the establishment of the Forestry Basic Act in 1964 (Table 6). The first stage is the resource creation policy period (1945-1964) before the establishment of the Forestry Basic Act. The second stage was between the establishment of the Forestry Basic Act and its amend- ment, titled the Forest and Forestry Basic Act (19642001), which can be divided into three policy periods. The third stage involves the implementation of the Forest and Forestry Basic Act since its establishment in 2001 (Endo, 2012; Kurisu, 1999).

The amendment of the Forestry Basic Act reflects the transformation of Japanese citizens' forest needs from timber production to multiple functions, which are including environmental functions of national land conservation and nature conservation and life functions of recreation, health care, natural education, and timber production. It also shows that the fiscal deficits of the Japanese government caused by domestic and international economic changes and forestry degradation have resulted in difficulties of forest maintenance and conservation (Forest Forestry Policy Research, 2002).

\section{Taiwan}

Because of the nationwide logging ban on natural forests in Taiwan, the developmental focus has shifted to forest recreation. The Forestry Bureau has started budgeting for recreational forests since 1966 (Lee and Hsu, 2010). The development of the forest recreation industry in Taiwan can be traced back to 1958, when the government of Taiwan Province implemented the

Table 6. Japan forestry administration periods

1. Resource creation policy (1945-1964)
$\begin{aligned} & \text { Japan lost the colonies of Korea and Taiwan as timber sources after WWII. To restore the forests that were destroyed } \\ & \text { and abandoned during the war, Japan actively launched reforestation projects. During the first decade of this effort, } \\ & \text { resources were created to achieve national land conservation, and during the subsequent decade, resources were } \\ & \text { created to ensure raw material production. }\end{aligned}$
2. Forestry Basic Act policy (1964-1980)

In response to the rapid increase of timber imports, Japan passed the Forestry Basic Act in 1964 to support domestic timber production. Since then, the Forestry Basic Act has become the principal axis of Japanese forestry policy. The Forestry Basic Act endeavored to modernize Japanese forestry and increase its efficiency. The act adopted the term "forestry" instead of "forest" to focus on forestry and forest operators instead of forest resources. Therefore, the act showed distinctive industrial policy characteristics.

3. Regional forestry policy (1980-1990)

During this period, the domestic timber consumption of Japan declined and the price of domestically manufactured lumber decreased. Forest policy objectives transformed from resource utilization to conservation. This policy intended to unify a series of forestry and forest industry activities (e.g., afforestation, timber production, and wood processing and distribution) within a region.

4. Watershed forestry policy(1990-2001)

Because the fiscal deficits of Japanese national forest management continued to worsen and the environmental awareness of Japanese citizens increased, the concerns for forests and environmental issues grew during this period. Therefore, the watershed forestry policy that aimed for forest conservation and diversified forest management objectives was promoted since 1990. The main contents of the watershed forestry policy were forming a complete watershed unit with the upstream and downstream of government-owned and privately owned forests, and achieving diversified forest maintenances using "green and water" resources. Watershed forestry policy emphasized the environmental and public welfare functions of forests.

5. Forest and Forestry Basic Act (2001-present)

In response to the international emphasis on global environmental issues, Japan has actively participated in international environmental protection affairs and has enthusiastically promoted the signing of the Kyoto Protocol. The forestry policy of Japan has also transformed from the Forestry Basic Act, which focused on achieving government-assisted forestry and forest industry production, to the Forest and Forestry Basic Act that emphasizes the development of multifunctional forests. 
Table 7. Taiwan forestry policy periods

\begin{tabular}{|c|c|}
\hline \multicolumn{2}{|c|}{ 1. Forestry policy in the early years of Taiwan's Retrocession (1945-1958) } \\
\hline 1956 & $\begin{array}{l}\text { The key administration points were forest protection, forest restoration, and an increase of logging, afforestation, and } \\
\text { National Treasury transfers with the goals of reforestation, forest conservation, and wealth creation. Forestry } \\
\text { management during this period was focused on forest conservation by balancing between planting and logging. } \\
\text { The first national aerial and forest resources survey was conducted. }\end{array}$ \\
\hline \multicolumn{2}{|c|}{ 2. Taiwan Forestry Policy and Management Guideline (1958-1975) } \\
\hline 1958 & $\begin{array}{l}\text { This forestry policy emphasized both conservation and production. The annual yield of harvested timber increased } \\
\text { from } 1.5 \text { million to } 2 \text { million cubic meters under the guideline. } \\
\text { Taiwan Forestry Policy and Management Guideline was enacted. }\end{array}$ \\
\hline \multicolumn{2}{|c|}{ 3. Taiwan Forest Management Reform Plan (1975-1991) } \\
\hline 1976 & $\begin{array}{l}\text { The three principles of forestry policy were established by the Executive Yuan: national land conservation as a long- } \\
\text { term goal, water and soil conservation enhancement, and a gradual reduction of logging operations. } \\
\text { The Taiwan Forest Management Reform Plan was the major basis for administration, with the goal shifting from timber } \\
\text { production to national land conservation. }\end{array}$ \\
\hline 1985 & The Forest Act was amended with the main objective focused on the long-term benefits of national land conservation. \\
\hline \multicolumn{2}{|c|}{ 4. Taiwan Forest Management Plan (1991-present) } \\
\hline & $\begin{array}{l}\text { A nationwide logging ban on natural forests and forests in reservoir watershed areas, ecological protection areas, } \\
\text { nature reserves, and national parks was implemented. Under this ban, the annual volume of logging must be less than } \\
200,000 \text { cubic meters. The plan emphasizes national land conservation, resource preservation, environmental } \\
\text { protection, and forest recreation. }\end{array}$ \\
\hline
\end{tabular}

Source: Lai (2002)

Managerial Principle and Policy for the Forest Industry in Taiwan. The twenty-first article of this policy highlighted the need to develop the forest recreation industry. After 1958, Taiwan's economy experienced a significant boost that resulted in a continuously increase in GDP. Thus, people in Taiwan had more leisure time to pursue recreational activities that enhanced their lives, and they experienced a gradual improvement in their material conditions. Consequently, Article 13 of the Reformation Plan for Forest Management in Taiwan issued by the Taiwan Provincial Government in 1976 explicitly highlights the need to "develop multiple uses of government-owned forests, establish natural and ecological protection and forest recreation areas, preserve the intactness of natural scenes, and protect the propagation of rare animals and plants for the purposes of scientific research, education, and improving people's health and happiness." In 1985, an investigation and evaluation of the forest recreational resources owned by the government was completed. In the same year, the Forestry Bureau organized the Forest Recreation Group and amended and issued the Forest Act, the seventeenth article of which explicitly stated that "forest recreation areas may be established in forests depending on environmental conditions, and the regulations for their establishment and management will be designated by the central competent authority." In 1992, Taiwan's provincial government issued the Guidelines for Government or Privately-Owned Forest Recreation Areas in Taiwan to plan the privatization of restaurant and hotel businesses in forest recreation areas. To date, the total number of forest recreation areas people can travel to is 22, of which the Cilan and Mingchih Forest Recreation Areas are managed by the Forest Conservation and
Management Administration, Veterans Affairs Commission, Executive Yuan. The Xitou and Huisun areas are respectively managed by the Experimental Forests of National Taiwan University and National Chung Hsing University, and the rest are managed by the Forestry Bureau, Council of Agriculture (Forestry Bureau, 2012).

Although many laws and regulations related to forest recreation have been enacted, only two laws remain: the Forest Act and the Taiwan Forest Management Plan. Article 1 of the Forest Act clearly states that the Forest Act was enacted for the purposes of preserving forest resources and developing the public and economic uses of forests. Amendments related to forest management and use have been continuously added to the act. Articles 12, 17, and 56 reflect the recent focus on forest recreation in Taiwan. Specifically, Article 17 states that forest recreation areas may be established within a forest region after passing an environmental impact assessment. Article 12 states that the main legal basis for forest recreation in Taiwan is the Taiwan Forest Management Plan. Apart from basic related regulations, the Taiwan Forest Management Plan includes a nationwide logging ban on natural forests.

The postwar forestry policy implementation in Taiwan can be divided into four periods based on three regulations, the Taiwan Forestry Policy and Management Guideline, the Taiwan Forest Management Reform Plan, and the Taiwan Forest Management Plan (Table 7).

\section{CURRENT FORESTRY ORGANIZATIONS}

\section{Japan}

The institution in charge of the forest and forestry 


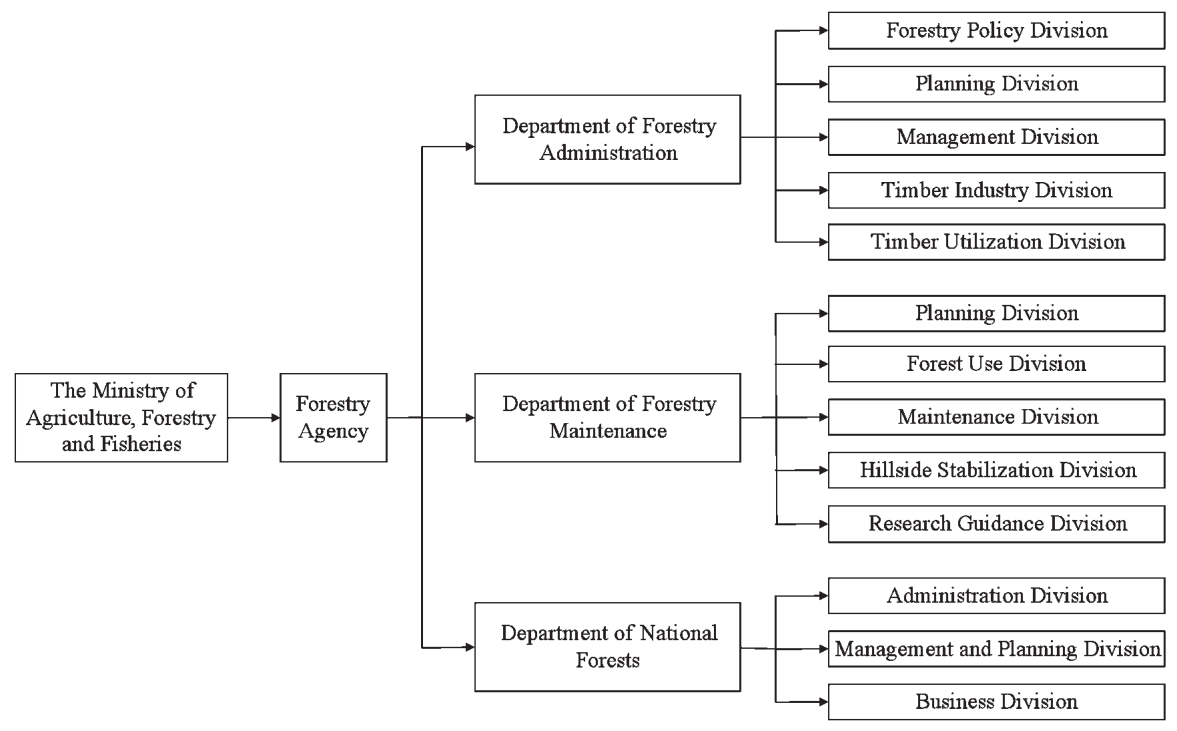

Fig. 1. Organizational Chart of Japan's Forestry Agency. Source: Forestry Agency (2013a)

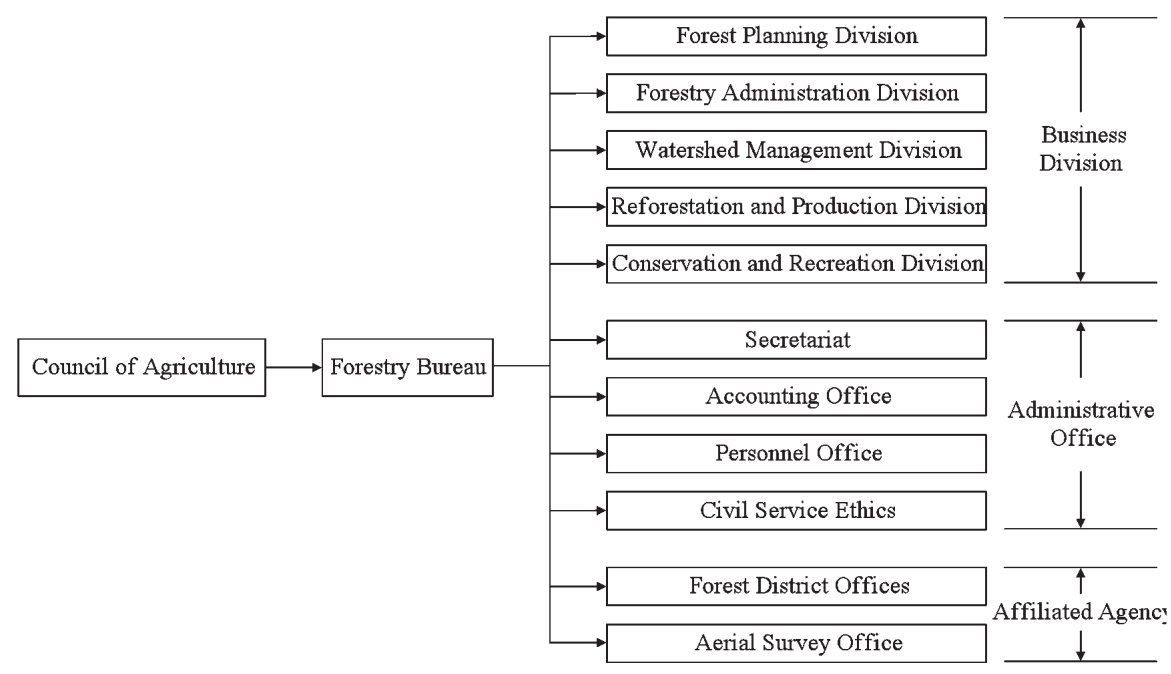

Fig. 2. Organizational Chart of Taiwan's Forestry Bureau. Source: Forestry Bureau (2005a)

affairs in Japan is the Forestry Agency under the Ministry of Agriculture, Forestry, and Fisheries. The Forestry Agency has three departments: the Department of Forestry Administration, the Department of Forest Maintenance, and the Department of National Forests. The Department of Forestry Administration oversees forest planning, the finance and taxation system, forestry structural adjustments and management improvements, as well as timber production, distribution, and consumption. The Department of Forest Maintenance is responsible for forest planning, mountain village revitalization, afforestation of privately owned forests, construction of forest roads, hillside stabilization planning, mountain area disaster countermeasures, as well as the research, development, and dissemination of forestry technology. The Department of National Forests is in charge of the administration and management of national forests (Fig. 1). The Forestry Agency includes a large network of local branches, comprising 7 forest administration bureaus, 98 forest management agencies, and forest science and technology training center (Forestry Agency, 2013a).

\section{Taiwan}

The Forestry Bureau, Council of Agriculture, Executive Yuan oversees the forest and forestry affairs in Taiwan. The Forestry Bureau has five business divisions (i.e., the Forest Planning, Forestry Administration, Watershed Management, Reforestation and Production, and the Conservation and Recreation divisions) and four administrative offices (i.e., the Secretariat, Personnel Office, Accounting Office, and Civil Service Ethics 
Committee). Affiliated agencies comprise eight regional forest district offices (located in Luotong, Hsinchu, Dongshih, Nantou, Chiayi, Pingtung, Taitung, and Hualien) and an Aerial Survey Office. Additionally, 34 workstations have been established for each forest district office. Because of high demands for business affairs, an additional coastal forest workstation was installed for the Hsinchu Forest District Office using task forces (Forestry Bureau, 2005a).

\section{FORESTRY ISSUES AND COUNTERMEASURES}

\section{Japan}

The issues of current forest management and forestry in Japan comprise three aspects: the continuous decline of economic benefits of forestry, decrease in forest management and protection standards, and substantial accumulated debt of government-owned forestry. The continuous decline of forestry economic benefits was caused by the import expansion of timber and wood products into Japan and the stable domestic demand for timber, lowered prices of log, timber, and wood products (Sato, 2013). Meantime, costs such as forestry wages and seedling fees have greatly increased. These conditions have resulted in a substantial reduction of forestry benefits. The proportion of forestry revenues in the total income of foresters has continuously declined as well. Because of the decline of forestry benefits, an increasing number of officers related forest have abandoned the management and protection of forests. Because of the lack of management and protection, the crown illumination within certain forests has reduced, causing ground vegetation to wither and subsequent top soil loss. In addition, Japanese state forest has continuously suffered from deficits in the past years because of changes in the greater forestry environment (Kasahara, 1995).

Japan was obligated to reconsider its forest and forestry management and policy to respond to the above issues. In addition to having a stable wood prices, Japan should be more transparency in policy-making (Sato, 2013). The Forest Policy Reform Outline and Forest Policy Reform Plan were proposed as response strategies (Endo, 2012). The key points of this policy reform are as follows:

\section{Transforming policy concepts}

The former policy direction of expanding timber production was transformed into continuous development of multifunctional forests and the practice of sustainable forest management. In other words, forest management cannot solely consider constant timber harvesting. This new policy concept necessitates the understanding and evaluating the value of forests from multiple angles that include biodiversity protection, water and soil conservation and preservation, natural environment protection, public health, and prevention of global warming (Endo, 2012).

2. Re-creating functional distinctions among forests and practicing classified management
The classification of forest functions in Japan has been changed, ranging from three kinds of classification (water and soil conservation forests, forests in symbiosis with humans, and resource reuse forests) to more flexible classification based on local conditions. There is a significant change in 2011, following the revised Forest Law, zoning categories and the methods must be decided by local government (municipalities). It is one of the decentralization policies. Central government showed some exemplary categories for municipalities. In order to get the proportion of forests for public welfare, it is one of the decentralization policies (Shiraishi, 2012).

3. Complete reform of the state forest

Based on related bills for state forestry reform enacted in 1998, Japan has implemented a series of reform projects regarding state forestry. After 2009, under the political change from the Liberal Democratic Party to the Democratic Party, there are some changes. The basic guidelines of national forests include the following two aspects: (a) Forest management guidelines shifted from emphasizing timber production function to focusing on public welfare functions. At the same time, the state forest must contribute to the achievement of self-sufficiency target, which was set the rate, over $50 \%$ by 2019. (b) A highly efficient state forest management system was implemented. In practice, government functions are limited to plan formulation, forest management and protection, and the implementation of hillside stabilization works, whereas logging and afforestation are commissioned to private sectors. In addition, the number of personnel in state forestry departments is reduced accordingly (Fukuda, 2012).

\section{Taiwan}

The current issues of forest management and forestry in Taiwan comprise two aspects: an extremely low self-sufficiency rate of timber supply and related hazards caused by poor management and protection of forest compartments. The low self-sufficiency rate of timber supply is caused by the logging ban of the Taiwan Forest Management Plan on natural forests and the area constraints of plantation logging. Recently, the annual timber demand of Taiwan has exceeded 6 million cubic meters, and $99 \%$ of the demand is fulfilled by imports. However, countries in Southeast Asia have started limiting their timber exports to protect their forest resources; thus, Taiwan may soon encounter a timber shortage. In addition, some of the government-owned forest compartments in Taiwan have not been restored from previous overuse and deforestation, resulting in water and soil hazards during the monsoon seasons. To improve these problems, this study recommends the following measures:

1. Sustainable management and use of timber

The conflict between economic utilization and nature conservation necessitates a transformation of the Taiwan forestry to provide a stable timber supply. Specifically, conservation, development, and utilization should be equally emphasized (Lee and Hsu, 2010). The hillsides should be delineated into forestry manage- 
ment regions during government-owned land planning, and modern silviculture techniques should be used to breed new varieties to enhance forest growth. As draw on Japan's practices, the forests can be classified into plantation areas for management and well-maintained roads and new silviculture techniques can be employed to increase production and achieve sustainable management. Besides increasing the production, assurance of timber quality and sources are crucial for sustainable timber use. The costs of manual harvesting are high in Taiwan, and, thus, the sales price of domestically manufactured timber must be set high to generate profits. This research recommends authentication measures for lumbering.

2. Reinforce hillside afforestation to reduce hazards

Taiwan has previously implemented regulations for reforestation on leased forest land, which was intended to accelerate the greening of government-owned land using private fund and human resources. However, tenants of many forest areas had not fulfilled reforestation according to the contract; thus, this research suggests that the government recover those areas. The National Land Restoration Act drafted by the Executive Yuan should be implemented in phases. In addition, a Taiwanese national database of forest and water resources should be established to understand past disasters for the delineation of preservation areas according to terrain, nature of soil, and natural environment (Chen and Hsieh, 2007). Although the water and soil preservation policy in Taiwan seems better than the policy in Japan, the policy implementation in Taiwan is poor than Japan. Therefore, Taiwan should follow Japan's example of establishing conservation forests for water and soil conservation in hazardous mountain areas, and should focus on hillside stabilization achieve forest protection.

3. Development of community forestry

In 2002, the Forestry Bureau proposed a community forestry project to encourage and assist community residents to participate in forest management. Most community forestry operators emphasize recreational functions, followed by resource survey, afforestation, and greening. Clearly, plans related to eco-tourism account for a significant portion of community forestry. Community forestry development is used to prompt community residents to proactively participate in forestry management, and is designed to generate concerns regarding local land and forest resources. The community forestry project involves residents' gradual process of learning and adjusting along with the mountain communities, enabling them to emulate the Japanese policy of mountain village revitalization to create self-sufficient community forestry (Forestry Bureau, 2005b).

\section{CONCLUSION}

The Forest and Forestry Basic Act of Japan was established based on forest and forestry implementation policies. Taiwan established the Forest Act in 1985 that possesses a function and legal position similar to Japan's
Forest and Forestry Basic Act. The characteristics of Japanese forestry policy are that it aims excellent forest conservation through industrial and rural development policies instead of direct forest resource control and management. The Forest and Forestry Basic Act endeavors to stabilize the forestry development by increasing total forestry production and forestry productivity, and to promote the socioeconomic status of forest workers by increasing their income. Consequently, forest workers are expected to be willing to maintain and protect forest resources. The concept underlying this act is consistent with the sustainable forest management principles proposed by the United Nation in 1992, indicating that forest conservation must accommodate social, economic, and cultural developments to succeed (Zheng, 2007). Rural development policy may not be enough. In particular, it should not only by increasing the income of forest workers to maintain forest resources, but also by increasing people's environmental education. When amending related laws and regulations, Taiwan has considered the social demands for forest recreation, but has overlooked the issues of domestic timber self-sufficiency. Whether this policy direction can achieve sustainable forest management warrants further research.

Japan and Taiwan have both experienced hillside hazards; therefore, policies are required to maintain the intactness of natural forests. In addition, the public currently emphasizes recreation and are close to nature; thus, developing forest recreation, natural education, and community forestry are imperative. Taiwan values forest recreation development significantly, and has substantially profited from the practice. Japan should enhance its promotion of forest recreation to increase profits and subsequently mitigate the fiscal deficits of state forest. Environmental education and community forestry can educate the public on the importance of ecological conservation and the special products of their surrounding forests, encouraging them to proactively participate in forest maintenance and reforestation. Finally, the two countries should focus on increasing their timber self-sufficiency rates or seeking multiple options to alleviate timber supply shortage (Mochida, 2012). Japan and Taiwan share the following future directions regarding forestry: (a) enhance forest management to reduce potential hillside hazards; (b) support the revitalization of rural village forests and encourage the citizens to participate in forest diversification activities to increase forest recreation profits; and (c) emphasize sustainable use of timber and forest ecological sustainability to increase the domestic timber selfsufficiency rate. In order to achieve the above objectives, future research should seek to understand how to reduce potential hillside hazards, how to support the revitalization of rural village forests, and how to achieve sustainable use of timber. In conclusion, the future forestry goals of both countries include balancing the ecological and economic functions of the forests to achieve sustainable forest management. 


\section{REFERENCES}

Cabinet Office 2007 The Public Opinion Survey on life and forest. Cabinet Office, Tokyo (in Japanese)

Cabinet Office 2011 The Public Opinion Survey on life and forest. Cabinet Office, Tokyo (in Japanese)

Chen, H. H. and Y. N. Hsieh 2007 A study on benefits of forests in public welfare. Quarterly Journal of Chinese Forestry, 40(1): 135-145 (in Chinese)

Endo, K. 2012 Development of forest policy process in Japan. In "Revision- Modern forest policy studies", ed. by K. Endo, J-FIC, Tokyo, pp. 47-70 (in Japanese)

Forest Forestry Policy Research 2002 New forest, forestry basic policies. Earth, Inc., Tokyo (in Japanese)

Forestry Agency 2011 Annual report on forest and forestry in Japan - Fiscal year 2011. Forestry Agency, Tokyo (in Japanese)

Forestry Agency 2013a Forestry Agency head office organization chart. Forestry Agency, Tokyo (in Japanese)

Forestry Agency 2013b Forestry policy chronology. http://www.rinya.maff.go.jp/j/kouhou/nenpyou.html Retrieved March 20, 2013 (in Japanese)

Forestry Bureau 2005a Council of Agriculture, Forestry Bureau's 1993 Annual Report. Council of Agriculture, Taipei

Forestry Bureau 2005b Operating specifications of the Community Forestry Program. Council of Agriculture, Taipei (in Chinese)

Forestry Bureau 2012 Forest recreation policies blueprint. http://recreation.forest.gov.tw/lib/lib_1_1_2.aspx Retrieved November 19, 2012 (in Chinese)

Forestry Bureau 2013a Forestry Statistics eBook. http://www.forest.gov.tw/ct.asp?xItem $=56643 \&$ ctNode $=4474 \&$ $\mathrm{mp}=1$ Retrieved March 22, 2013

Forestry Bureau 2013b The forest in Taiwan as time flies. http://theme.coa.gov.tw/suggest.php?issue $=13669 \& i d=13670$ Retrieved March 19, 2013 (in Chinese)

Fukuda, T. 2012 National forests. In "Revision- Modern forest policy studies", ed. by K. Endo, J-FIC, Tokyo, pp. 211-223 (in Japanese)

Huang, K. J. 2005 A literature-review study on Transformation of Timber Production Institution in Taiwan. Master's Thesis,
National Taiwan University, Taipei (in Chinese)

Kasahara, Y. 1995 Consequences of National Forest Policy in the Postwar Japan and Its Problems for the 21st Century. The Japanese Forest Economic Society, 127: 23-32 (in Japanese)

Kurisu, Y. 1999 Changes in forestry policy after World War II. Research and information, 156: 3-4 (in Japanese)

Lai, C. H. 2002 Current and future status of forestry management in Taiwan. In "How to promote timber technology training seminar handbook" ed. by Council of Agriculture, National Chiayi University, Chiayi, pp. 42-45 (in Chinese)

Lee, J. S. and P. H. Hsu 2010 The History of Forest Management and Recreation Development in Taiwan After World War II. Quarterly Journal of Forest Research, 32(1): 87-96 (in Chinese)

Liu, M. F. 2004 The health benefit of forest recreation. Master's Thesis, National Taipei University of Nursing and Health Sciences, Taipei (in Chinese)

Mochida, H. 2012 Forestry Revitalization Plan. In "RevisionModern forest policy studies", ed. by K. Endo, J-FIC, Tokyo, pp. 71-81 (in Japanese)

Nagasakiya, K. 2005 Changes in functional areas of forest. In "Evaluation of forest function", ed. by Y. Konohira, J-FIC, Tokyo, pp. 63-71 (in Japanese)

Sakai, M. 2004 The concept of forest policy studies. In "Forest Policy", ed. by M. Sakai, J-FIC, Tokyo, pp. 25-32 (in Japanese)

Sato, N. 2013 Position of Mountainous Area Issues on the Process of Policy Making and the Implementation of "Forest and Forestry Revitalization Plan". Journal of Forest Economics, 59(1): 15-26 (in Japanese)

Shiraishi, N. 2012 Forest management and forest planning system. In "Revision- Modern forest policy studies", ed. by $\mathrm{K}$ Endo, J-FIC, Tokyo, pp. 123-136 (in Japanese)

Totman, C. 1989 The Green Archipelago: Forestry in Preindustrial Japan. Univ. of California Press, Berkeley

Wang, C. C. 2005 The implement action of forest, health and leisure. Journal of sport and recreation management, $2(1)$ 23-39 (in Chinese)

Yao, H. N. 2004 Historical subject of the Taiwan Forestry Series (6)-Taiwan excessive logging era background. Taiwan Forestry Journal, 30(2): 51-61 (in Chinese)

Zheng, C. L. 2007 The forestry policy in Japan. National Taiwan Univ. Press, Taipei (in Chinese) 